Meta

Journal des traducteurs

Translators' Journal

\title{
Making Translations More « Native »: The Use of Feminine Pronoun for Inanimate Things
}

\section{Lorraine Neufeld}

Volume 35, numéro 4, décembre 1990

URI : https://id.erudit.org/iderudit/003726ar

DOI : https://doi.org/10.7202/003726ar

Aller au sommaire du numéro

Éditeur(s)

Les Presses de l'Université de Montréal

ISSN

0026-0452 (imprimé)

1492-1421 (numérique)

Découvrir la revue

Citer cet article

Neufeld, L. (1990). Making Translations More « Native »: The Use of Feminine Pronoun for Inanimate Things. Meta, 35(4), 742-747.

https://doi.org/10.7202/003726ar d'utilisation que vous pouvez consulter en ligne. 


\section{MAKING TRANSLATIONS MORE "NATIVE": THE USE OF THE FEMININE PRONOUN FOR INANIMATE THINGS}

LORRAINE NEUFELD

Markham, Ontario, Canada

In a television interview, an Albertan farmer speaks excitedly about "the old girl" and how "great she looks." One senses the affection with which he uses these terms. Yet, is he referring to his wife? his mother? a faithful mare? No, he is referring to a steamengine train that he has been working on for 20 years and is about to ride to Vancouver.

In much the same way, Leopold, in Michel Tremblay's play "Forever Yours, MarieLou," frets and fumes over the piece of machinery with which he has worked daily for the past 27 years:

You know all her tricks, you know them so well it's like you were born with her, like she was your first toy. I was hardly more than a kid when they tied me to that goddamned thing and I've still got 20 years to go! Hell, in 20 years there'll be nothing left of me. I'm already a wreck. And in 20 years, boy, it's not you they're going to retire, it's that machine! (Tremblay, Trans. Glassco and Van Burek, 1975; 46).

Although Leopold curses the machine, the audience senses his attachment to it. Tremblay could very easily have written the play in English - Leopold's lament comes across as crass, incongruous and "native" in translation as it does in the original French text. This effect has been achieved through both the use of coarse language and, more importantly, the calling into play of a hidden system of gender distinction. It is the subtle use of she and her in reference to the machine which makes Leopold seem as much a native English speaker as the Albertan.

"Gender" in English is primarily a matter of the choice of the three personal (or possessive) pronouns of the third person singular (he, him, his/she, her, hers/it, its) to refer to a preceding noun. Traditional grammar holds that the use of he is limited to the masculine gender, she to the feminine and it to the neuter case (Miller and Swift, 1976: 43). Translators, however, must recognize that modern usage does not necessarily abide by this rule and that the English language has a gender distinction which for a great number of nouns differs according to context and point of view. Writers of English cannot ignore the fact that objects, such as machines or ships, and abstract nouns, such as liberty and mercy, are frequently referred to by the feminine pronoun. As seen in the translation of "Forever Yours, Marie-Lou," a general understanding of how and when feminine pronominal referents are used may render a translation more "native" and in so doing increase the reader's enjoyment of a piece of literature.

The use of the feminine pronoun in reference to inanimate things and abstract nouns has been a subject of controversy in recent years. In the 1985 edition of The Canadian Style, under the heading "Elimination of Sexual, Racial and Ethnic Stereotyping in Written Communication," writers are told to:

Avoid using the feminine pronoun to personify animals, events, ships, etc.:

NOT

Meta, XXXV, 4, 1990 
Once again the area was hit by hurricane Flora. She wrought havoc.

BUT

... It wrought havoc.

(Canada, Department of the Secretary of State, 1983: 234)

The controversy over this issue appears to stem from the fact that, historically, people in search of a general rule to explain the use of the feminine pronoun have made sweeping, frequently sexist, assertions. In Structural Essentials of English, Harold Whitehall purports that in the English system of hidden gender distinction, "power represents the masculine, grace the feminine." He provides two examples to support his theory:

Before I boated him, the tuna gave me a real fight.

As she came around the bend, the train was a fine sight.

(Whitehall, 1956: 110)

According to A Handbook of English Grammar, abstract nouns, such as peace and mercy, which suggest gentleness are feminine (Zandvoort, 1965: 133). Referring to author L. Morsbach, T. Hilding Svartengren in "The Use of the Personal Gender for Inanimate Things" writes:

The author regards it as a thing of general application and psychologically natural to assign feminine gender to what is mild, gentle and weak, and masc. [sic] gender to all that is violent, forceful and strong. He puts the matter, as he thinks, in a nutshell by saying that the needle is made fem., the sword, masc. (Svartengren, 1928: 50)

Given such sweeping generalizations, it is little wonder that many people react negatively to female-specific reference to certain nouns.

In particular, activists in the feminist movement have reacted to the grammarians' claim. Although they concede that the grammar books portray actual usage, they are against such generalizations being taken for English grammar rules. Many feminists focus their attention on the literary tradition, which promotes the notion that power is masculine, and gentleness and grace are feminine. Greek mythological tradition, for instance, is to blame for celestial bodies (moon, earth) and abstract nouns (fortune, liberty, nature) being considered inherently feminine. In Greek mythology, the abstract and phenomenal world was personified as gods and goddesses, "who duplicated the social stereotypes and biological roles of males and females" (Gershuny, 1977: 115). Thus, Earth, with steadfast, giving qualities mirroring the qualities of women in Greek society became female specific:

Earth, the beautiful rose up,

Broad bosomed, she that is the steadfast base

Of all things...

(Edith Hamilton, Mythology, 1942: 64, cited in Gershuny, 1977: 115)

Death and war were made into gods because they brought to mind the masculine traits of strength and terror. Scholars attuned to sexism in language react to images perpetuated in contemporary literature, as in the science fiction novel Adam and No Eve by Alfred Bester, in which the use of the feminine pronoun in reference to inanimate things is blatantly sexist:

There need be no Adam - no Eve. Only the sea, the great mother of life was needed. The sea had called him back to her depths that presently life might emerge once more, and he was content. 
Quietly the waters rocked him. Quietly - Calmly - the mother of life rocked the last born of the old cycle who would become the firstborn of the new.

(Bester, cited in Gershuny, 1977: 115)

Others in the feminist movement, much like the grammarians, have contrived their own rule to explain the use of the feminine pronoun in reference to inanimate things. Their rule is based not as much on physical qualities as on what they perceive to be a male desire to control. Julia P. Stanley in Sexism and Language writes:

One way of accounting for these metaphorical extensions of female-specific reference derives from the male point of view, which assumes male dominance and male control of the earth, the world, all the land, and the oceans. All these things are regarded as their possessions. As one legal textbook defines the situation: "land, like women, is for possessing." (Stanley, 1977: 66)

As this group sees it, men postulate women as a goal outside themselves to be mastered and conquered, so that anything overwhelming in nature is feminine, such as Mother Earth, Hurricane Ida and the sea, as is anything difficult or big, such as ships, mines and dams (Varda One, cited in Thorne and Henley, 1975: 224).

Although grammarians and feminists may find numerous examples to support their views, it is not difficult to find an equal number of instances in which they are contradicted. Svartengren writes of gunplay, fire-barrels and rifles denoted by the feminine pronoun. Such examples refute the notion that force represents the masculine, as do the following two quotations taken from American novels:

Storm's here at last... She's worse than that other one... She didn't come any too soone, did she? (Bower, PH: 222 cited in Svartengren, 1928: 38)

They ain't looking for no trouble — they just goes around blowin'off. Trouble! Why they don't know what she is. (Mulford, Bar 20: 66 cited in Svartengren, 1928: 32)

Those who blame classical literature for the "feminization" of the abstract and phenomenal world seem to ingore the influence of Latin on the English language. In Latin, a language with an established grammatical gender, fortuna, liberta and natura are feminine. In English literature, the sun is always masculine, while other celestial bodies, such as the moon, are feminine, just as sun (sol) is masculine and moon (luna) is feminine in Latin. If the feminine pronoun is used to show male control, one must question the use of such a referent by a female, as in the following instance:

We'll have to stir this camp up a bit and make her seem like old times. I'm afraid you boys have been getting a little slow, she flashed good-humouredly at the others. (White, W.: 198 cited in Svartengren, 1928: 24)

Why are the names of countries as political or economic units feminine while as geographical units they are neuter?

France has been able to increase her exports by 10 per cent over the last six months.

Looking at the map we see France here. It is one of the largest countries of Europe. (Quirk and Greenbaum, 1973: 93)

It becomes clear that there is no hard and fast rule in English to dictate the use of the feminine pronoun in reference to inanimate things. Nevertheless, the fact that various groups have proposed rules and have found numerous examples to support their theories underscores the importance of context and point of view in the functioning of the hidden gender systems. 
Results of a study carried out in 1973 and recorded in American Speech 48 confirm the impossibility of establishing a rule. In this study, native English speakers were given declarative sentences for which they were to formulate tag questions using pronouns to denote the subject of each sentence. Sentences dealt with subjects such as countries, boats, babies and animals. Within each subject area, there were sentences with no overt gender marker as well as sentences including semantic markers in the form of adjectives or verbs implying sex or syntactic markers in the form of pronouns. Thus, a sentence such as, "America will always defend her overseas interests," contains a syntactic clue in the form of her, while, "America supports the United Nations," has no marker (Marcoux, 1973: 100). The researchers found that, "while two-thirds of the informants demonstrated feminine gender agreement with countries when a pronoun marker was in the sentence, fewer than half did so when no marker was provided" (Marcoux, 1973: 101). In the case of ships, they concluded that, "the occurrence of the feminine pronoun agreement with common nouns referring to ships is uncommon." To a sentence such as, "The boat is sinking," 97 informants formed a tag question with $i$, while only three used she (Marcoux, 1973: 103). This investigation reveals that gender agreement is not as obvious as sometimes assumed; the respondants did not consistently choose pronouns according to the so-called grammatical gender of nouns or even according to the natural gender of nouns such as baby. Marcoux adds that, "since the group composed of informants who should be more aware of their language [university English majors] did not differ markedly from the other groups tested, the effects of grammatical training would seem to be negligible" (Marcoux, 1973: 107).

Examples of the seemingly indiscriminate use of the feminine pronoun have been recorded by T. Hilding Svartengren. In his 1928 article, "The Use of the Personal Gender for Inanimate Things," Svartengren provides over 200 quotations, taken from an equal number of American novels, in which the feminine pronoun denotes inanimate things among these are guns, houses, rooms, pictures, films, newspapers, clothing, businesses, towns, roads, nature, celestial bodies, weather conditions, human body parts and plants. The writer also includes expressions denoting action and expressions with and without substantial propwords which contain the feminine pronoun. While close study of the quotations reveals the impossibility of establishing a general rule, it does make one aware of certain tendencies. One notes that the feminine pronoun is used, for the most part, by male speakers. Its use is reserved almost exclusively to colloquial and literary discourse. Sentences containing the feminine pronoun in reference to inanimate things are frequently characterized by movement. And, perhaps most important of all, the feminine pronominal referent is used more to show a personal interest in the antecedent noun than to mark its gender. While it states a fact, more or less coldly or indifferently, she unveils the speaker's emotions concerning the fact.

Some grammarians make reference to the notion of personal interest and familiarity implicit in the choice of she (her, hers). In A University Grammar of English, authors Quirk and Greenbaum state that when countries, ships and cars (things they call higher, non-personal organisms) are referred to as she, an affectionate attitude is being expressed (Quirk and Greenbaum, 1973: 93). Although he claims that abstract nouns that suggest gentleness are feminine, Zandvoort also writes:

She (her) are occasionally used with reference to plants and, rather oftener, to artificial objects, to express affection or familiarity.

Among the latter are ships, by whatever names they are called (boats, frigates, schooners, submarines, etc.); also engines, trains, motors, balloons, aeroplanes, etc., whose main characteristic feature is movement. (Zandvoort, 1965: 131) 
In Present-Day English Syntax, author Scheuerweghs implies the notion of personal interest when he writes, "Names of inanimate things are usually neuter, but nouns denoting cars, locomotives, machines, aircraft, tools are often used with feminine pronouns in the language of those who use them" (Scheuerweghs, 1959: 109). Kruisinga and Erades, in An English Grammar, claim that the feminine pronoun is "chiefly found in the language of those who come in frequent professional contact with the things in question."

Draws beautiful now, don't she? (The reference is to a chimney by a sweep) Dorothy $L$. Sayers, Busman's Honeymoon.

Will you please return my story immediateiy? If you don't want her, I want her. Edna Ferber (in a letter to a publisher, quoted in Ill. London News, May 27, 1939: 924)

(Kruisinga and Erades, 1967: 449-450)

This "insiders" use of she and her may, in fact, explain the findings of Marcoux. The surveyed informants may have used it more often than she in their responses to sentences involving ships and countries because they did not feel a closeness to the antecedent nouns. The test situation or their unfamiliarity with these objects may have coloured their responses.

One can think of a number of reasons to explain why she is used in reference to inanimate things more frequently than he. Foremost would be the idea that if one chooses to treat an object as a person to whom one takes a fancy, one is most likely to make that object a member of the opposite sex. Quirk and Greenbaum make the remark that, "the proud owner of a sports car may refer to it as she (or perhaps as he if the owner is female)" (Quirk and Greenbaum, 1973: 93). However, in an informal, personal study, I have noted that in the few instances where women personify their cars, they too use the feminine pronoun. Objects, such as engines, ships and airplanes are more frequently denoted by the feminine pronoun than by the masculine because men tend to handle these objects more often than women, and thus develop a greater attachment to them. Although the male tradition has carried on in terms of sports cars, one wonders if the use of she (her, hers) in reference to such objects will diminish as women become more active in non-traditional, male-dominated endeavours.

A final explanation for the frequent use of the feminine pronoun among men might be found in the linguistic behaviour of both men and women. It has been found that women are more concerned with grammatical correctness and use third person pronouns less frequently than men (Lynette Hirschman in Thorne and Henley, 1975: 232; Lakoff, 1975: 55). In his preface to the Dictionary of American Slang, Flexer writes: "In my work on this dictionary, I was constantly aware that most American slang is created and used by males" (Flexer cited in Thorne and Henley, 1975: 52). Women are more likely to refer to an object by its full name or it than to personify it. This would help explain why one seldoms hears of machines traditionally handled by women, such as washing machines and vacuum cleaners, referred to as she or he.

Other linguistic studies have indicated that while women speak predominantly about internal states and behaviours, using words implying feeling and motivation, men's speech is characterized by action (Nancy Barron in Thorne and Henley, 1975: 228; Jane Schuster in Thorne and Henley, 1975: 236). If such is the case, it would account for the correlation, noted by Zandvoort, between the predominantly male use of the feminine pronoun and movement. A significant number of Svartengren's quotations are spoken by men, imply movement and demonstrate affection (often in terms of emotionality imperative or exclamatory sentences): 
Let her zip! (Bennett, GS: 222)

"I can't back out now,"/the gambler/said. "If I'm wrong, I sleep in the streets, anyway. I'll call your hundred and shoot the rest of my roll." "Ride "er, cowboy," said Lonesome with a grin. (WSM, 14, 111, 1925: 49)

It was beautiful to hear that clock tick, and sometimes when one of these pedlars had... scoured her up and got her in good shape she would start in and strike a hundred and fifty... (Twain, HF: 135)

(All quoted in Svartengren, 1928: 16-31)

Contrary to what many grammarians and feminists would have us believe, no abstract idea or inanimate thing is inherently masculine or feminine, nor is the use of the feminine pronoun in reference to such nouns necessarily sexually discriminatory. These viewpoints, however, should not be ignored in any attempt to understand the use of the feminine pronominal referent, just as the roles played by tradition, linguistic inheritance and behaviour and, most importantly, emotions should not be overlooked. All of these factors underscore the importance of context and point of view in the functioning of the hidden gender system and ... make the translator's job all the more difficult. While use of the feminine pronoun may make certain texts more "native" or help define personalities and attitudes more succinctly, as translators, we must consider the context and decide whether a female-specific reference to an inanimate thing is appropriate, lest we become unintentional perpetuators of sexual stereotypes.

\section{REFERENCES}

CANADA, DEPARTMENT OF THE SECRETARY OF STATE (1985): The Canadian Style, Toronto, Dundem Press Limited.

GERSHUNY, H. Lee (1977): "Sexism in the Language of Literature," in Sexism and Language, A. P. Nilsen, H. Bosmajian, H. Lee Gershuny, J. P. Stanley, Urbana, Illinois, National Council of Teachers of English. KRUISINGA, E. and P. A. ERADES (1967): An English Grammar: Accidence and Syntax, Groningen, P. Noordhoff.

LAKOFF, Robin (1975): Language and Woman's Place, New York, Harper \& Row.

MARCOUX, Dell R. (1973): "Deviation in English Gender," in American Speech 48, pp. 98-107.

MILLER, Casey and Kate SWIFT (1976): Words and Women, Garden City, N.Y., Anchor Press / Doubleday.

QUIRK, Randolph and Sidney GREENBAUM (1973): A University Grammar of English, London, Longman Group Limited.

SCHEVERWEGHS, G. (1959): Present-Day English Syntax, London and Harlow, Longmans Green and Co. Ltd.

STANLEY, Julia P. (1977): "Gender-Marking in American English: Usage and Reference," in Sexism and Language, A. P. Nilsen et al., Urbana, llinois, National Council of Teachers of English.

SVARTENGREN, T. Hilding (1928): "The Use of the Personal Gender for Inanimate Things," in Dialect Notes 6, University of Alabama Press, pp. 7-56.

THORNE, Barrie and Nancy HENLEY, comp. (1975): "Sex Differences in Languages, Speech, and Nonverbal Communication: An Annotated Bibliography," in Language and Sex, B. Thorne and N. Henly, ed., Rowley, Mass., Newbury House Publishers Inc.

TREMBLAY, Michel. Translated by Bill Glassco and John Van Burek (1975): Forever Yours, Marie-Lou, Vancouver, Talonbooks.

WHITEHALL, Harold (1956): Structural Essentials of English, New York, Harcourt, Brace \& World, Inc.

ZANDVOORT, R. W. (1965): A Handbook of English Grammar, London, Longmans, Green and Co. Ltd. 